\title{
Autoimmune autonomic neuropathies and ganglionopathies: epidemiology, pathophysiology, and therapeutic advances
}

\author{
Elisabeth P. Golden ${ }^{1}$ (D) . Steven Vernino ${ }^{1}$ (D) \\ Received: 1 March 2019 / Accepted: 3 May 2019 / Published online: 15 May 2019 \\ (c) Springer-Verlag GmbH Germany, part of Springer Nature 2019
}

\begin{abstract}
Autonomic disorders can be the result of autoimmunity. The classic, well-characterized example is autoimmune autonomic ganglionopathy (AAG), in which antibodies against the ganglionic nicotinic acetylcholine receptor impair autonomic transmission, causing autonomic failure, which responds to immunotherapy. However, a number of other autoimmune disorders cause autonomic failure through a variety of mechanisms. In this article, we review autoimmune disorders causing impairment of the peripheral autonomic nervous system (ganglia and nerves), including AAG, other autoimmune autonomic neuropathies, paraneoplastic autonomic neuropathies, and neuromuscular and rheumatologic diseases with autonomic symptomatology. Awareness of primary autoimmune autonomic disorders and the autonomic manifestations of other autoimmune diseases promotes timely diagnosis and appropriate management, including supportive care for unpleasant or dangerous autonomic dysfunction, a search for underlying malignancy when indicated, and the use of immunotherapy when appropriate. A better understanding of the underlying pathophysiology aids in the judicious use and selection of immunotherapy.
\end{abstract}

Keywords Autoimmune autonomic ganglionopathy $\cdot$ Autoimmune autonomic neuropathy $\cdot$ Paraneoplastic autonomic neuropathy $\cdot$ Immunotherapy

\section{Introduction}

The pathophysiology of autonomic failure is diverse. Mechanisms include toxic/metabolic (diabetes, amyloid), genetic defects (hereditary sensory and autonomic neuropathies), structural (baroreceptor injury), neurodegenerative $(\alpha$-synucleinopathies), and autoimmune. Localization may be anywhere along the neuroaxis from central autonomic networks in the brain to peripheral small nerve fibers. In this article, we will review autoimmune disorders causing impairment of the peripheral autonomic nervous system. These include primary autonomic disorders such as autoimmune autonomic ganglionopathy, autoimmune and paraneoplastic autonomic neuropathies, and rheumatologic diseases with autonomic manifestations; see Tables 1 and 2. Checking for potential autoimmunity in autonomic disorders is important as it permits the identification of patients who

Elisabeth P. Golden

Elisabeth.golden@utsouthwestern.edu

1 Department of Neurology and Neurotherapeutics, University of Texas Southwestern Medical Center, 5323 Harry Hines Blvd. MC 9368, Dallas, TX 75390, USA might benefit from immunotherapy in addition to standard supportive care, and an awareness of autonomic manifestations in other autoimmune diseases ensures that unpleasant or dangerous autonomic symptoms are appropriately managed. The evaluation and management of these patients is often complex, given the nonspecific symptoms, difficulty establishing objective evidence of autoimmunity, and rarity of these diseases (making data regarding treatment scarce). See Fig. 1 for a summary of the general approach to a patient with a suspected autoimmune peripheral autonomic disorder.

\section{Autoimmune autonomic ganglionopathy}

The first case of presumed autoimmune disease restricted to the autonomic nervous system was reported by Young and colleagues in 1969 as "pure pan-dysautonomia with recovery" [1,2]. Further description of the condition was limited to case reports until a larger series of "idiopathic autonomic neuropathy" was published in 1994 [3]. Subsequently, the entity now known as "autoimmune autonomic ganglionopathy" (AAG) was characterized clinically and pathophysiologically, with the ganglionic nicotinic acetylcholine receptor (gAChR) antibody identified as the cause in many cases. 
Table 1 Autoimmune disorders of the peripheral autonomic nervous system

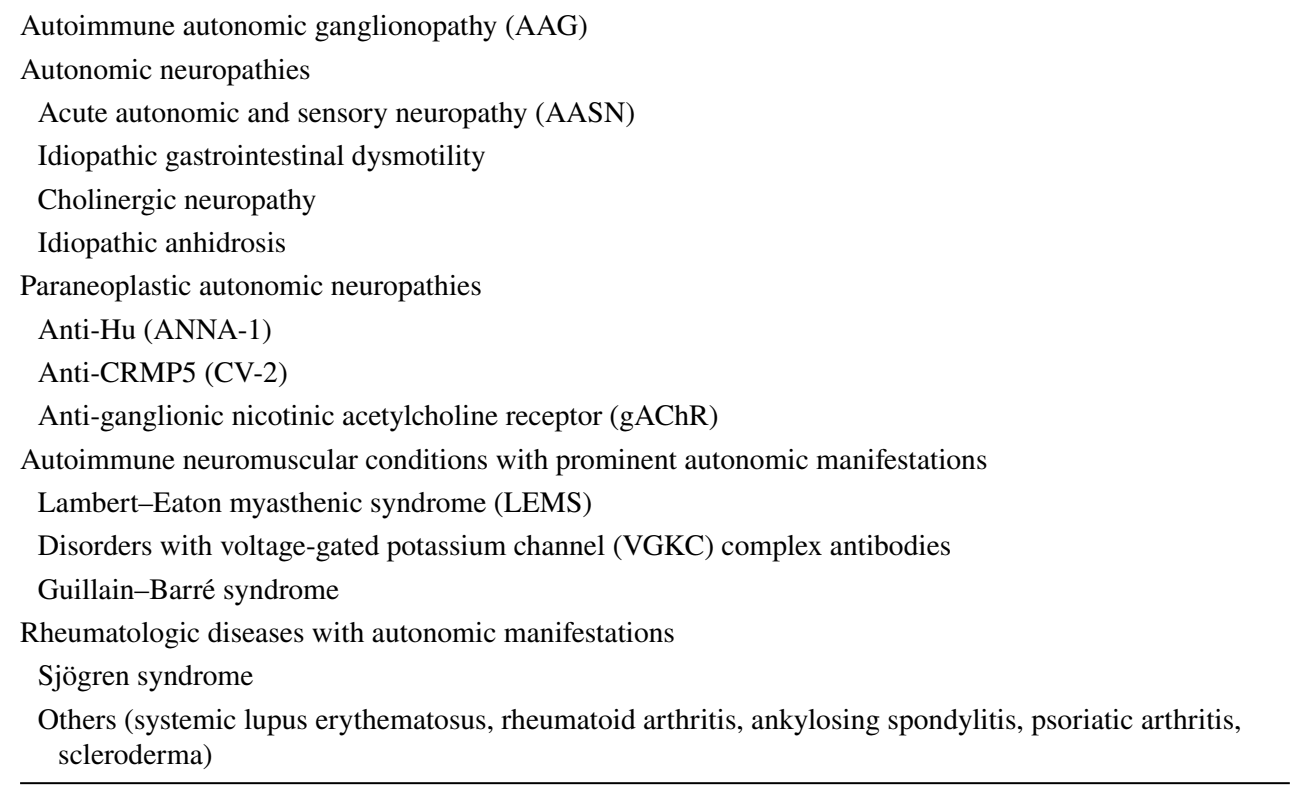

AAG is a rare disease. Patients are typically middle-aged (mean ages 45-61), with a 2:1 female predominance [3,4]. The classic presentation is acute to subacute, often with an antecedent event. However, the identification of the causative antibody also allowed for identification of a chronic phenotype (clinically similar to pure autonomic failure), which accounts for about half of seropositive patients [4]. Patients typically manifest diffuse failure of sympathetic, parasympathetic, and enteric systems. The most common symptom is orthostatic hypotension $(\mathrm{OH})$, and cholinergic failure is prominent, including sicca syndrome (dry mouth and dry eyes), poorly reactive pupils, anhidrosis, upper and lower gastrointestinal dysfunction, and neurogenic bladder. Symptoms can be severe, with a significant impact on quality of life. Spontaneous recovery (typically incomplete) is seen in about one-third of patients [3, 4]; improvement is also seen with immunomodulatory therapy, as described below.

About a quarter [3,5] to half [6] of patients report subjective paresthesias, but pain is not a feature of this disease, and objective evidence of somatic nerve dysfunction is not seen. Cognitive impairment is occasionally reported [6-9] and may be independent of $\mathrm{OH}[10]$. Several additional features have been reported in Japanese cohorts, including psychiatric symptoms, coughing episodes, and endocrine dysfunction $[5,6,11]$.

Laboratory autonomic testing reveals diffuse autonomic failure, with the Composite Autonomic Severity Score (CASS) [12] indicating moderate to severe impairment [3, 4]. Both ganglionic and post-ganglionic sudomotor deficits may be seen [13]. Quantitative pupillometry reveals premature pupillary redilation to prolonged light stimulus ("pupillary fatigue"); see Fig. 2. This is a unique feature of AAG and is hypothesized to represent impairment of ganglionic synaptic transmission similar to the muscular fatigue of myasthenia gravis [14]. Nerve conduction studies and electromyography are typically normal. CSF analysis may reveal mildly elevated protein without pleocytosis [3]. Sural nerve biopsy may show decreased numbers of small fibers and other nonspecific abnormalities [3, 15-18].

About half of patients with AAG are found to have antibodies against the ganglionic nicotinic acetylcholine receptor (gAChR) $[5,19]$, which mediates fast synaptic transmission at all autonomic ganglia. The gAChR comprises two $\alpha 3$ subunits and three other subunits (usually $\beta 4$ ). The antibodies in AAG bind specifically to the $\alpha 3$ subunit [20]. As this subunit is specific to the ganglionic receptor, there is minimal cross-reactivity between antibodies against gAChR and antibodies against the muscle AChR (which cause myasthenia gravis) [21, 22].

Several lines of evidence have established the pathogenicity of $\alpha 3 \mathrm{gAChR}$ antibodies in AAG. In vitro, the application of IgG from AAG patients decreases gAChR current in cultured neuroblastoma cells [23]. Mice with genetically engineered null mutations in the $\alpha 3$ subunit show decreased autonomic ganglionic transmission, with a clinical phenotype of urinary retention, dilated and nonreactive pupils, and increased mortality [24]. Active immunization of rabbits against the $\alpha 3$ subunit produces an experimental model (EAAG) characterized by gastrointestinal hypomotility, urinary retention, and impaired pupillary light reflex, with a reduction in $\mathrm{gACh}$ receptors on postsynaptic ganglionic neurons and impaired synaptic transmission $[25,26]$. EAAG rabbits also demonstrate the premature pupillary redilation seen in AAG patients [27]. Passive antibody transfer also causes disease: mice treated with $\mathrm{IgG}$ from affected rabbits or humans develop self-limited autonomic failure [28]. 


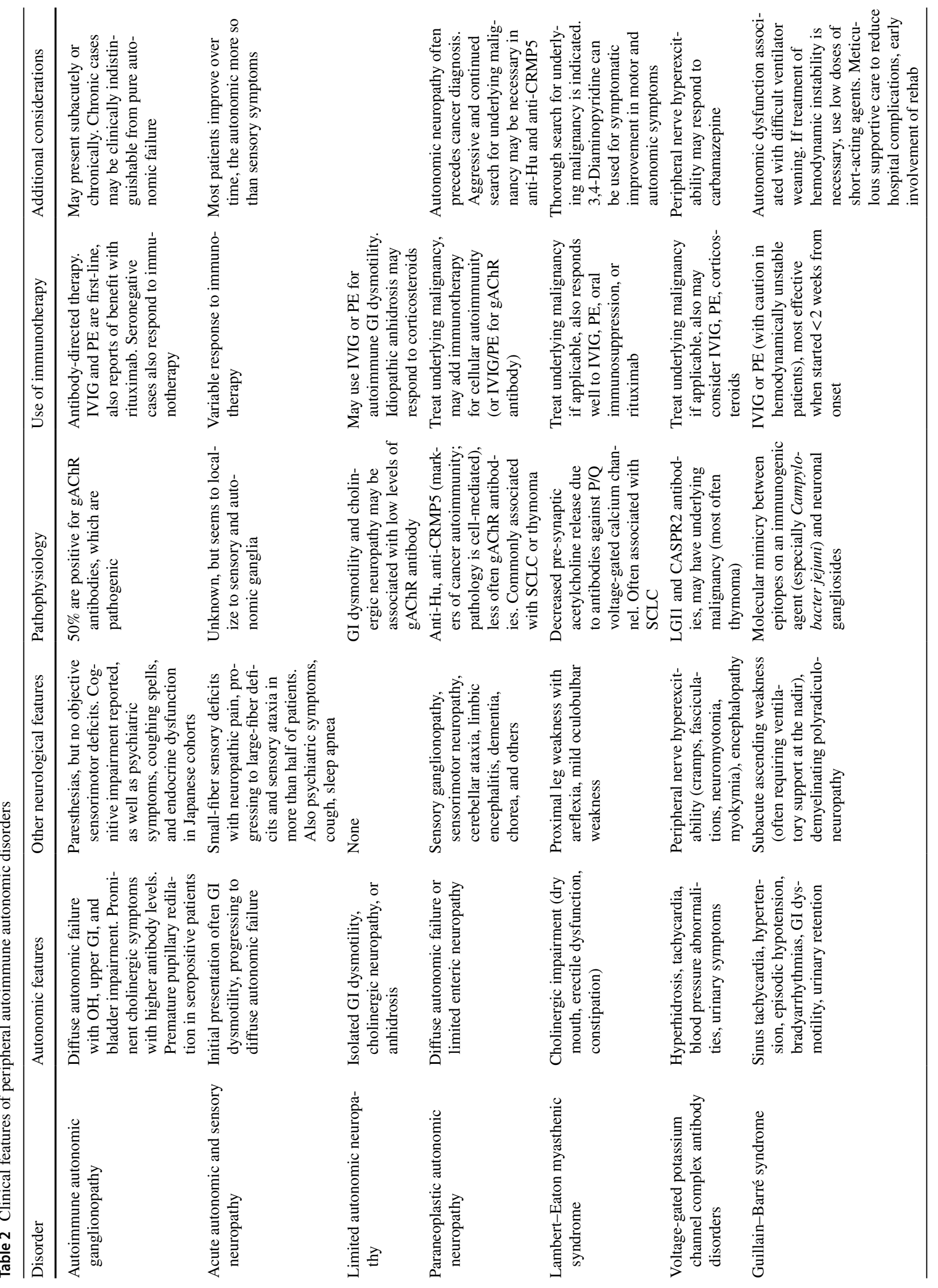




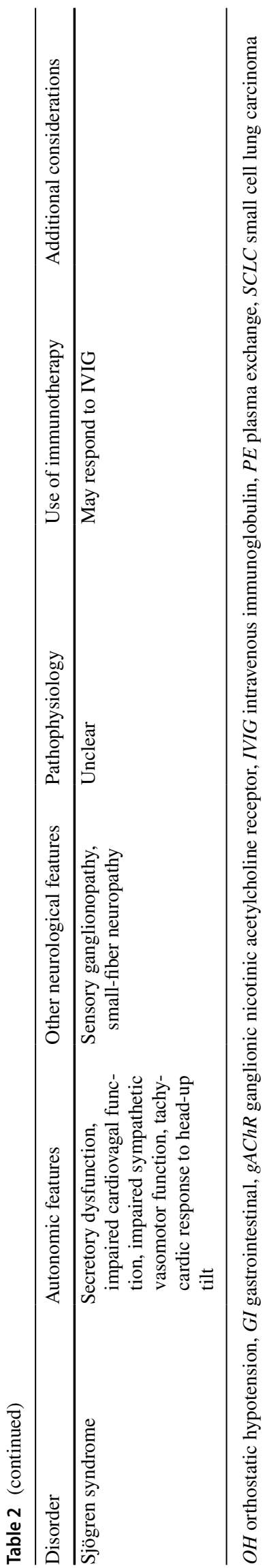

Transient neonatal AAG from maternal antibodies has also been reported [29].

Antibody levels are clinically meaningful, based on a characterization of seropositive AAG patients. Levels above $0.20 \mathrm{nmol} / \mathrm{L}$ are fairly specific for AAG [30]. High levels correlate with overall disease severity, prominent cholinergic symptoms [4, 31], and orthostatic hypotension, which becomes clinically significant and increasingly severe with antibody levels $>1 \mathrm{nmol} / \mathrm{L}$ [31]. Antibody levels are not, however, associated with the acuity of the clinical course (subacute vs. chronic presentations) [4, 31]. Antibody levels fall with spontaneous recovery [19] and track with the clinical course after plasmapheresis [32, 33].

Treatment of AAG is directed at the antibody-mediated pathology. Due to the rarity of the disease, evidence is limited to case reports and series; see Table 3. Antibody depletion via plasma exchange (PE) or modulation with intravenous immunoglobulin (IVIG) appears to be beneficial and is considered first-line therapy [34-37]. Combination therapy with immunosuppressant medications may yield an additional benefit $[32,35,36]$. In particular, rituximab, a B cell depleting agent which would decrease antibody production, has shown promise [38-43]. Supportive symptomatic treatment should also be offered as indicated, including nonpharmacologic and pharmacologic management of orthostatic hypotension, cholinergic agents and artificial tears and saliva for sicca symptoms, bowel regimen for constipation, and urologic management of neurogenic bladder.

\section{Seronegative autonomic ganglionopathy and neuropathy}

About half of cases of idiopathic subacute autonomic failure are seronegative for gAChR antibodies [19]. Seropositive cases are more likely to have prominent cholinergic failure and pupillary abnormalities [44]. Response to immunotherapy has been reported in seronegative cases [35, 45].

A recent case series of six patients [46] described a distinct subset of seronegative autoimmune autonomic failure. These patients presented with acute to subacute onset of orthostatic hypotension and gastrointestinal symptoms; three had prominent sensory deficits and severe neuropathic pain. The pattern of autonomic failure was different than seropositive AAG, with predominant sympathetic deficits. There was poor response to standard AAG immunotherapy, and remarkable response to high-dose steroids in three of the patients. Length-dependent sensory symptoms and QSART deficits suggested localization of the pathology to the nerve (particularly small fibers) rather than the autonomic ganglia, and the response to steroids rather than antibody-targeted therapies (IVIG, PE, rituximab) suggested a cell-mediated or inflammatory mechanism rather than an antibody-mediated process. Whether 


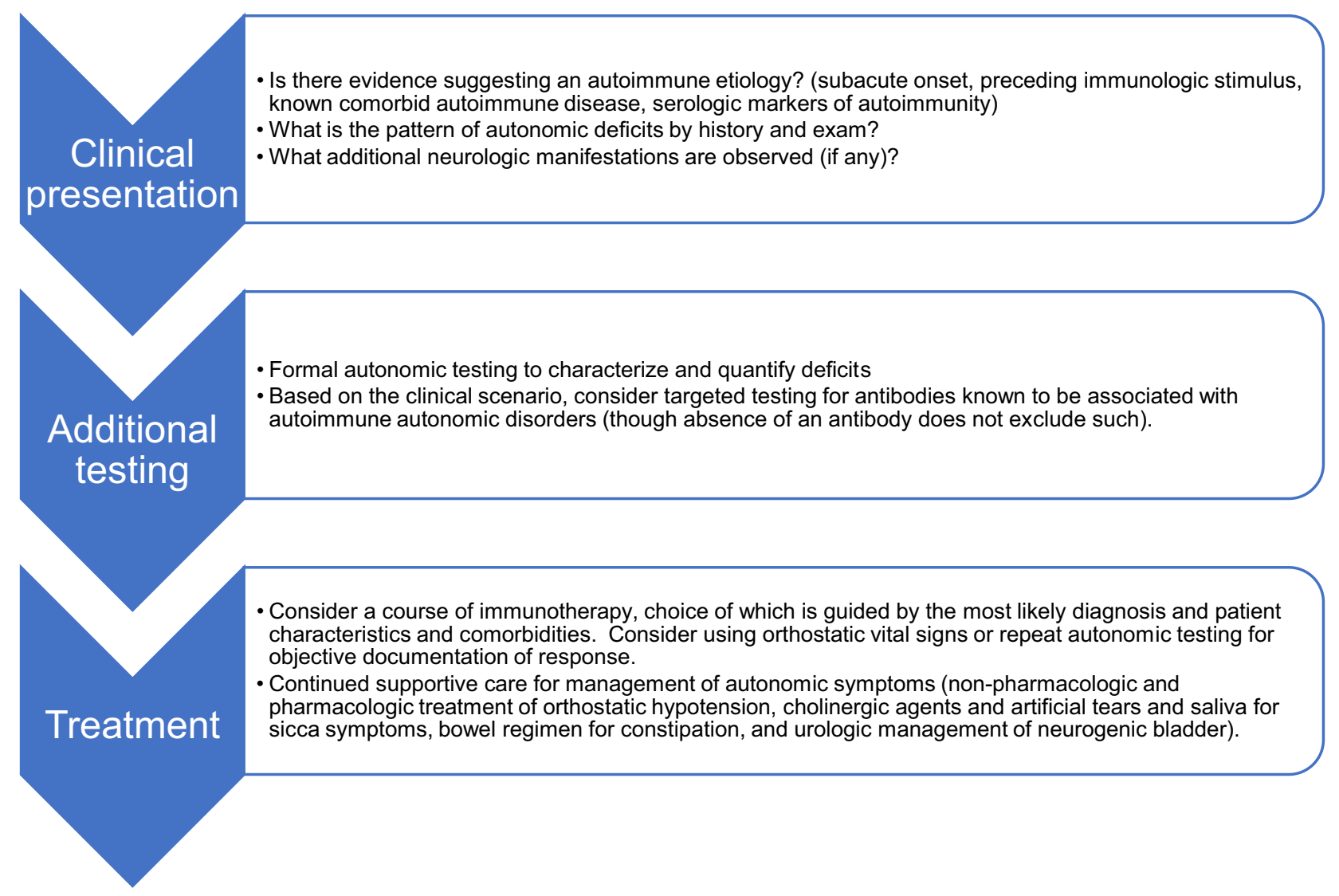

Fig. 1 Approach to a patient with a suspected peripheral autoimmune autonomic disorder

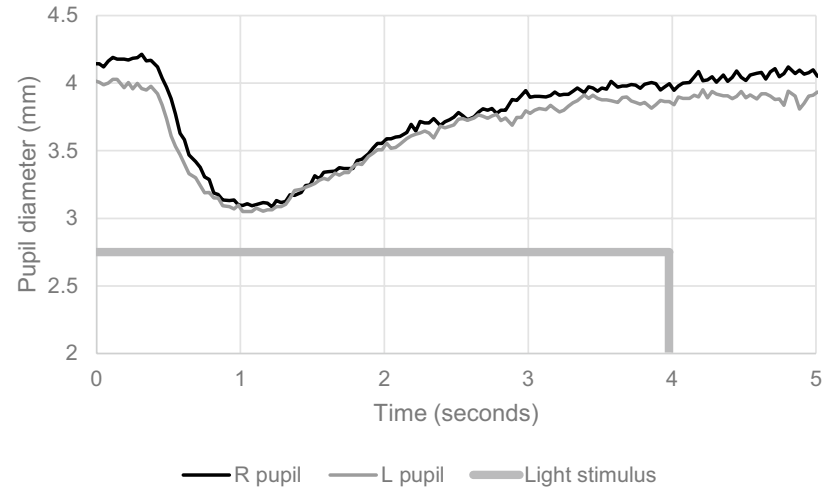

Fig. 2 Pupil reaction to prolonged (4 s) light stimulus in an autoimmune autonomic ganglionopathy patient. Note that the pupil redilates and returns to baseline despite continued light stimulus

these patients represent a distinct nosological entity or are more similar to acute autonomic and sensory neuropathy (discussed below) will require further study [47].

\section{Limited autonomic neuropathy}

Limited presentations of autonomic failure have been associated with gAChR antibodies, generally at levels ranging from 0.05 to $0.20 \mathrm{nmol} / \mathrm{L}$ [48]. Antibody positivity has been documented in $10 \%$ of patients with idiopathic gastrointestinal dysmotility [19], and as many as $50 \%$ of patients with chronic intestinal pseudo-obstruction [49]. Patients with chronic orthostatic hypotension, clinically similar to pure autonomic failure, may have positive antibodies and respond to immunotherapy [33]. Low levels of gAChR antibodies have been reported in a wide variety of autoimmune neurologic and rheumatologic diseases [30], malignancies [7, $19,30]$, and postural orthostatic tachycardia syndrome [19, 50-54]. The clinical significance of these results is unclear, and in most cases the antibody is likely a nonspecific reflection of underlying systemic autoimmunity.

Other limited forms of presumed autoimmune autonomic failure have also been described. Isolated cholinergic neuropathy without evidence of sympathetic vasomotor dysfunction has been reported [55]. These patients are sometimes positive for gAChR antibodies at low levels [48]. Idiopathic anhidrosis presents with heat intolerance due to inadequate sweating, with symptoms including skin 
Table 3 Immunotherapy for autoimmune autonomic ganglionopathy

\begin{tabular}{|c|c|c|}
\hline Treatment & Discussion & Selected references \\
\hline Intravenous immunoglobulin & $\begin{array}{l}\text { Generally regarded as first-line therapy. Multiple case reports with } \\
\text { benefit, though not all patients respond }\end{array}$ & Iodice [35], Iodice [37] \\
\hline Plasma exchange & $\begin{array}{l}\text { Generally regarded as first-line therapy. Clinical status may correlate } \\
\text { with antibody levels before and after exchanges }\end{array}$ & Schroeder [33], Imrich [39], Gibbons [32] \\
\hline Corticosteroids & $\begin{array}{l}\text { Not often used as monotherapy. May provide benefit as part of combi- } \\
\text { nation immunotherapy }\end{array}$ & Iodice [36] \\
\hline Rituximab & Multiple case reports of benefit & $\begin{array}{l}\text { Bouxin [42], Gupta [38], Hollenbeck } \\
\text { [40], Benizri [41], Dumitrascu [43] }\end{array}$ \\
\hline Mycophenolate mofetil & $\begin{array}{l}\text { Reports of benefit in several patients, both as monotherapy after first- } \\
\text { line therapy failed and as part of combination therapy }\end{array}$ & Iodice [35], Gibbons [32] \\
\hline Azathioprine & Occasional reports of benefit as part of combination therapy & Iodice [35], Schroeder [33] \\
\hline Combination therapy & $\begin{array}{l}\text { Addition of immunosuppressive therapy may provide additional } \\
\text { benefit when first-line therapies alone fail }\end{array}$ & Gibbons [32], Iodice [36] \\
\hline
\end{tabular}

flushing, lightheadedness, rash (cholinergic urticaria), and hyperhidrosis of areas with preserved sweat function (face, axillae, palms, and soles). The condition may respond to steroids, particularly if administered early in the course [56].

\section{Acute autonomic and sensory neuropathy}

Acute autonomic and sensory neuropathy (AASN) was first reported by Colan in 1980 [57]. Most of the literature consists of sporadic case reports, but a larger case series of 21 patients in Japan summarized the key features of the disease [58]. Presentation was acute, with an antecedent event (mostly upper respiratory tract infections) occurring in two-thirds of patients. Initial symptoms were sensory (numbness or pain) or autonomic (often gastrointestinal). These progressed to severe and diffuse autonomic failure (sympathetic, parasympathetic, and enteric), segmental small-fiber sensory deficits with prominent neuropathic pain, and sensory ataxia in more than half the patients. Autoimmune etiology was presumed based on acute onset with antecedent immunologic stimulus, and localization appeared to be at the level of the sensory and autonomic ganglia based on diffuse autonomic deficits, the segmental pattern of sensory involvement, and, in some patients, spinal cord imaging showing T2 hyperintensities in the dorsal columns. Response to immunotherapy was variable. Most patients showed improvement over time, albeit more so in cases with autonomic symptoms than in those with sensory symptoms. There are also reports in the literature of acute autonomic sensory and motor neuropathy (AASMN), but given the similarity to Guillain-Barré syndrome (a primary motor and sensory disease often with prominent autonomic manifestations), the existence of a distinct nosological entity is uncertain [55].

\section{Paraneoplastic autonomic neuropathy}

Autonomic neuropathy or ganglionopathy can be the result of a paraneoplastic process; see Table 4. Patients may present with subacute diffuse autonomic failure, clinically indistinguishable from AAG; the coexistence of additional features such as sensory ganglionopathy, limbic encephalitis, myasthenic syndrome, or cerebellar ataxia should heighten suspicion for a paraneoplastic process [59]. Patients may also present with a limited enteric neuropathy, with symptoms including dysphagia, nausea, and vomiting, bloating, early satiety, weight loss, and constipation. Motility abnormalities in these patients are varied, including achalasia, gastroparesis, chronic intestinal pseudo-obstruction, chronic constipation, and megacolon [60, 61]. Lambert-Eaton myasthenic syndrome and Morvan syndrome may also occur as paraneoplastic phenomena and are discussed further below. The paraneoplastic syndrome often precedes the diagnosis of cancer, which may be at an early and limited stage at presentation.

The most common antibodies associated with paraneoplastic autonomic neuropathy are anti-Hu (ANNA-1), antiCRMP5 (anti-CV2), and gAChR antibodies. Anti-Hu is highly associated with underlying malignancy (88\%), particularly small cell lung carcinoma (SCLC), whose diagnosis may be elusive [62]. $18 \%$ of patients with anti-Hu have features of autonomic neuropathy, and $12 \%$ may present initially solely with enteric neuropathy. Additional syndromes may include sensory or sensorimotor neuropathy, cerebellar ataxia, limbic encephalitis, and others [62]. Anti-CRMP5 is similarly highly associated with cancer (91\%), most commonly SCLC or thymoma. In addition to autonomic or enteric neuropathy, patients may exhibit somatic neuropathy, cerebellar ataxia, dementia, chorea, and cranial neuropathy [63]. Paraneoplastic disease due to gAChR antibodies is clinically indistinguishable from AAG. These antibodies 
Table 4 Paraneoplastic antibodies associated with peripheral autonomic failure

\begin{tabular}{|c|c|c|c|c|c|}
\hline Antibody & Autonomic manifestations & Other manifestations & $\begin{array}{l}\text { Cancer } \\
\text { frequency } \\
(\%)\end{array}$ & Cancer type & Antigen location \\
\hline Anti-Hu (ANNA-1) & $\begin{array}{l}\text { Diffuse autonomic failure, } \\
\text { enteric neuropathy }\end{array}$ & $\begin{array}{l}\text { Sensory ganglionopathy, } \\
\text { sensorimotor neuropathy, } \\
\text { cerebellar ataxia, limbic } \\
\text { encephalitis }\end{array}$ & 88 & SCLC & Intracellular \\
\hline Anti-CRMP5 (CV-2) & $\begin{array}{l}\text { Diffuse autonomic failure, } \\
\text { enteric neuropathy }\end{array}$ & $\begin{array}{l}\text { Somatic neuropathy, cer- } \\
\text { ebellar ataxia, dementia, } \\
\text { chorea, cranial neuropathy }\end{array}$ & 91 & SCLC, thymoma & Intracellular \\
\hline Anti-gAChR & $\begin{array}{l}\text { Diffuse autonomic failure, } \\
\text { enteric neuropathy }\end{array}$ & None & 15 & $\begin{array}{l}\text { SCLC, thymoma, adenocar- } \\
\text { cinomas }\end{array}$ & Cell surface \\
\hline Anti-P/Q VGCC & $\begin{array}{l}\text { Cholinergic impairment } \\
\text { (dry mouth, constipation, } \\
\text { erectile dysfunction) }\end{array}$ & $\begin{array}{l}\text { Proximal leg weakness with } \\
\text { areflexia, mild oculobulbar } \\
\text { weakness }\end{array}$ & 60 & SCLC & Cell surface \\
\hline Anti-VGKC complex & $\begin{array}{l}\text { Hyperhidrosis, tachycardia, } \\
\text { urinary symptoms, blood } \\
\text { pressure abnormalities, } \\
\text { postganglionic sudomotor } \\
\text { deficits }\end{array}$ & $\begin{array}{l}\text { Peripheral nerve hyperexcit- } \\
\text { ability, encephalopathy, } \\
\text { limbic encephalitis }\end{array}$ & $13-44$ & Thymoma, SCLC, other & Cell surface \\
\hline
\end{tabular}

$S C L C$ small cell lung carcinoma, $g A C h R$ ganglionic nicotinic acetylcholine receptor, $V G C C$ voltage-gated calcium channel, $V G K C$ voltage-gated potassium channel

are associated with underlying malignancy in a minority of cases (15\%) [30]. The classic association is with SCLC or thymoma [19], although a variety of other cancers have been identified with these antibodies, including lymphoma and adenocarcinomas [7].

Anti-Hu and anti-CRMP5 are both directed against intracellular antigens and serve as markers of underlying cancer autoimmunity rather than as pathogenic antibodies. Paraneoplastic neuronal injury in these conditions is cell-mediated and often irreversible [64]. Treatment of paraneoplastic neuropathies is first directed at identifying and eradicating the underlying malignancy. Additional immunotherapy can be offered with agents that target cellular autoimmunity.

\section{Lambert-Eaton myasthenic syndrome}

Autonomic symptoms are a common component of Lambert-Eaton myasthenic syndrome (LEMS). In addition to the motor symptoms (proximal leg weakness with areflexia, mild oculobulbar weakness), the vast majority of patients exhibit some degree of cholinergic autonomic impairment. The most common symptoms are dry mouth, erectile dysfunction, and constipation [65, 66]. The pathophysiology of LEMS is related to decreased presynaptic acetylcholine release due to antibodies against the P/Q voltage-gated calcium channel [67]. About $60 \%$ of cases are paraneoplastic, most commonly associated with SCLC, and there is a male predominance and older age of onset compared to non-paraneoplastic cases [66]. The diagnosis of LEMS should prompt a thorough and persistent search for underlying SCLC or other malignancy. The syndrome responds well both to treatment of the underlying cancer and to immunotherapy (IVIG, $\mathrm{PE}$, oral immunosuppression, or rituximab), and 3,4-diaminopyridine can be used for symptomatic improvement in motor and autonomic symptoms [68].

\section{Disorders with VGKC-complex antibodies}

Autonomic manifestations are often seen in disorders with antibodies against components of the voltage-gated potassium channel (VGKC) complex, including leucine-rich glioma inactivated protein 1 (LGI1) and contactin-associated protein-like 2 (CASPR2). These antibodies are clinically associated with Isaacs syndrome (peripheral nerve hyperexcitability), Morvan syndrome (peripheral nerve hyperexcitability, dysautonomia, and encephalopathy), and limbic encephalitis [69]. Autonomic impairment as well as hyperactivity can be seen in these patients. Hyperhidrosis is the most common autonomic symptom; those with Morvan syndrome may also have tachycardia, blood pressure abnormalities, and urinary symptoms [70]. Formal autonomic testing may reveal orthostatic hypotension and postganglionic sudomotor deficits [71, 72]. LGI1 and CASPR2 antibodies may be associated with thymoma (found in one-third of patients with Morvan syndrome [70]), SCLC [69], or other assorted malignancies (cancer detection 13\% in LGI1, 20\% in CASPR2, and 44\% in double-positive patients [71]). Management of disorders associated with VGKC-complex antibodies may include immunotherapy and an appropriate search for an underlying malignancy. 


\section{Guillain-Barré syndrome}

Autonomic dysfunction is common in Guillain-Barré syndrome (GBS), occurring in about two-thirds of cases. Manifestations of autonomic dysfunction are varied and may indicate hyper- or hypofunctioning of the sympathetic and/or parasympathetic nervous systems. Cardiovascular manifestations include most commonly sinus tachycardia, and also hypertension (which can be severe enough to cause posterior reversible encephalopathy syndrome), postural hypotension, reversible cardiomyopathy, episodic hypotension, and bradyarrhythmias, which can be life-threatening and may require pacemaker placement. Autonomic dysfunction is common amongst severely debilitated patients and can be associated with sudden death and difficulty with ventilator weaning; however, even patients with milder weakness can exhibit autonomic dysfunction [73, 74]. Other autonomic manifestations include gastrointestinal dysfunction such as paralytic ileus and diarrhea, urinary retention, increased or decreased sweat responses, and Horner syndrome [74, 75].

GBS is classically a post-infectious illness, in many cases reflecting molecular mimicry between epitopes on the infectious agent (especially Campylobacter jejuni) and neuronal gangliosides [76]. Several subtypes differ in their clinical and immunologic characteristics. Symptomatic autonomic dysfunction is more common in acute inflammatory demyelinating polyradiculoneuropathy (AIDP) than in the motor axonal (AMAN) or Miller Fisher variants [74]. The pathophysiology of autonomic dysfunction in GBS is not well understood [76].

Treatment of GBS consists of immunotherapy (either PE, which must be used with caution in patients with cardiovascular instability, or IVIG), careful monitoring for respiratory and autonomic deterioration in the acute phase, meticulous supportive care to avoid complications of hospitalization and immobility, and comprehensive rehabilitation [76]. Careful monitoring of blood pressure and heart rhythm should be undertaken in the acute phase, and transfer to intensive care is indicated for those exhibiting hemodynamic instability. GBS patients are often quite sensitive to the effects of vasoactive medications, so these should have a short halflife and be used sparingly [74, 77]. Similar to the somatic manifestations of GBS, clinical autonomic dysfunction typically resolves over time, although formal testing may reveal persistent subclinical deficits [74].

\section{Central autoimmune autonomic disorders}

A number of central autoimmune disorders also have autonomic manifestations. A study of 58 epilepsy patients with peri-ictal autonomic findings found a high prevalence (29\%) of neuronal autoantibodies [78]. In addition to the peripheral syndromes discussed above, VGKC-complex antibodies can cause limbic encephalitis with autonomic manifestations [71]. Anti-NMDA receptor encephalitis causes autonomic instability in $69 \%$ of patients, with manifestations including cardiac dysrhythmia, temperature and blood pressure fluctuations, hyperhidrosis, and sialorrhea [79]. Heart rate variability analysis suggests sympathetic dysfunction, and patients with impaired cardiac autonomic function may have poorer outcomes [80]. Antibodies against dipeptidyl peptidase-like protein-6 (DPPX) cause a syndrome of encephalopathy, central hyperexcitability, and autonomic manifestations primarily involving the gastrointestinal tract (diarrhea and weight loss) [81]. Serum from an anti-DPPX patient was shown to cause hyperexcitability of enteric neurons [82]. A substantial proportion of patients with multiple sclerosis have autonomic dysfunction, including impaired cardiovascular autonomic function as well as bowel, bladder, and sexual dysfunction. This is hypothesized to reflect not only demyelinating lesions in relevant parts of the brain and spinal cord, but also pathologic interactions between the dysregulated immune system and adrenergic receptors on lymphocytes [83]. Cardiac autonomic dysfunction and autonomic symptoms have also been reported in patients with neuromyelitis optica spectrum disorders (NMOSD) [84].

\section{Sjögren syndrome and other rheumatologic diseases}

Primary Sjögren syndrome (SS) is a rheumatologic disease characterized by sicca symptoms and lymphocytic infiltration of exocrine glands. Peripheral nervous system involvement may occur, particularly sensory ganglionopathy and small-fiber neuropathy [85]. More than half of SS patients report symptoms of autonomic dysfunction [86]. Objective characterization of autonomic manifestations has yielded varying results, including secretory dysfunction out of proportion to histological changes in the salivary gland [87], decreased cardiovagal function [87-89], impaired sympathetic vasomotor activity [90], and tachycardic response to head-up tilt [91]. Autonomic features may precede the diagnosis of SS [91]. The pathophysiology of autonomic dysfunction in SS is not well understood, although some patients may respond to immunotherapy [91].

Autonomic function has been studied in other rheumatologic diseases as well, although conclusions regarding the extent and prevalence of autonomic dysfunction are limited by widely varying methodologies and patient populations. Patients with systemic lupus erythematosus tend to have decreased heart rate variability and abnormalities on various components of the Ewing battery; these abnormalities do not tend to correlate well with disease activity $[92,93]$. Studies in rheumatoid arthritis have shown increased sympathetic nerve activity, reduced cardiac baroreflex sensitivity [94], and a variety of other markers of autonomic dysfunction 
[95]; these are also independently associated with pain [94] and less consistently with markers of inflammation [95]. Interestingly, a pilot study of rheumatoid arthritis and ankylosing spondylitis patients [96] demonstrated improvement in several markers of autonomic function after the initiation of synthetic or biologic disease-modifying antirheumatic drugs. Parasympathetic and sympathetic dysfunction has also been described in scleroderma [97] and psoriatic arthritis [98].

\section{Conclusion}

Autoimmunity may underly primary peripheral autonomic disorders, and autoimmune neurological and rheumatological diseases may have prominent autonomic symptoms. An understanding of the underlying pathophysiology aids in the appropriate use of immunotherapy as well as the appropriate management of autonomic symptoms.

\section{Compliance with ethical standards}

Conflict of interest Dr. Golden has no conflict of interest to report. Dr. Vernino has received research support from Grifols, Genentech, Dysautonomia International, and Theravance.

Ethical statement The manuscript does not contain clinical studies or patient data.

\section{References}

1. Young RR, Asbury AK, Adams RD, Corbett JL (1969) Pure pandysautonomia with recovery. Trans Am Neurol Assoc 94:355-357

2. Young RR, Asbury AK, Corbett JL, Adams RD (1975) Pure pandysautonomia with recovery. Description and discussion of diagnostic criteria. Brain J Neurol 98(4):613-636

3. Suarez GA, Fealey RD, Camilleri M, Low PA (1994) Idiopathic autonomic neuropathy: clinical, neurophysiologic, and follow-up studies on 27 patients. Neurology 44(9):1675-1682

4. Klein CM, Vernino S, Lennon VA, Sandroni P, Fealey RD, Benrud-Larson L, Sletten D, Low PA (2003) The spectrum of autoimmune autonomic neuropathies. Ann Neurol 53(6):752-758. https ://doi.org/10.1002/ana.10556

5. Nakane S, Higuchi O, Koga M, Kanda T, Murata K, Suzuki T, Kurono H, Kunimoto M, Kaida K, Mukaino A, Sakai W, Maeda Y, Matsuo H (2015) Clinical features of autoimmune autonomic ganglionopathy and the detection of subunit-specific autoantibodies to the ganglionic acetylcholine receptor in Japanese patients. PLoS One 10(3):e0118312. https://doi.org/10.1371/journ al.pone. 0118312

6. Nakane S, Mukaino A, Maeda Y, Higuchi O, Matsuo H, Ando Y (2017) Extra-autonomic manifestations in autoimmune autonomic ganglionopathy: a Japanese survey. J Neurol Neurosurg Psychiatry 88(4):367-368. https://doi.org/10.1136/jnnp-2016-314707

7. McKeon A, Lennon VA, Lachance DH, Fealey RD, Pittock SJ (2009) Ganglionic acetylcholine receptor autoantibody: oncological, neurological, and serological accompaniments. Arch Neurol 66(6):735-741. https://doi.org/10.1001/archneurol.2009.78
8. Baker SK, Morillo C, Vernino S (2009) Autoimmune autonomic ganglionopathy with late-onset encephalopathy. Auton Neurosci 146(1-2):29-32. https://doi.org/10.1016/j.autneu.2008.10.016

9. Kuki I, Kawawaki H, Okazaki S, Hattori Y, Horino A, Higuchi O, Nakane S (2016) Autoimmune autonomic ganglionopathy in a pediatric patient presenting with acute encephalitis. Brain Dev 38(6):605-608. https://doi.org/10.1016/j.braindev.2015.12.009

10. Gibbons CH, Centi J, Vernino S, Freeman R (2012) Autoimmune autonomic ganglionopathy with reversible cognitive impairment. Arch Neurol 69(4):461-466. https://doi.org/10.1001/archneurol .2011 .2372

11. Hayashi M, Ishii Y (2009) A Japanese case of autoimmune autonomic ganglionopathy (AAG) and a review of AAG cases in Japan. Auton Neurosci 146(1-2):26-28. https://doi.org/10.1016/j. autneu.2008.12.013

12. Low PA (1993) Composite autonomic scoring scale for laboratory quantification of generalized autonomic failure. Mayo Clin Proc 68(8):748-752

13. Kimpinski K, Iodice V, Sandroni P, Fealey RD, Vernino S, Low PA (2009) Sudomotor dysfunction in autoimmune autonomic ganglionopathy. Neurology 73(18):1501-1506. https://doi. org/10.1212/WNL.0b013e3181bf995f

14. Muppidi S, Scribner M, Gibbons CH, Adams-Huet B, Spaeth EB, Vernino S (2012) A unique manifestation of pupillary fatigue in autoimmune autonomic ganglionopathy. Arch Neurol 69(5):644648. https://doi.org/10.1001/archneurol.2011.2143

15. Low PA, Dyck PJ, Lambert EH, Brimijoin WS, Trautmann JC, Malagelada JR, Fealey RD, Barrett DM (1983) Acute panautonomic neuropathy. Ann Neurol 13(4):412-417. https://doi. org/10.1002/ana.410130407

16. Feldman EL, Bromberg MB, Blaivas M, Junck L (1991) Acute pandysautonomic neuropathy. Neurology 41(5):746-748

17. Appenzeller O, Kornfeld M (1973) Acute pandysautonomia. Clinical and morphologic study. Arch Neurol 29(5):334-339

18. Koike H, Hashimoto R, Tomita M, Kawagashira Y, Iijima M, Koyano S, Momoo T, Yuasa H, Mitake S, Higashihara M, Kaida K, Yamamoto D, Hisahara S, Shimohama S, Nakae Y, Johkura K, Vernino S, Sobue G (2012) The spectrum of clinicopathological features in pure autonomic neuropathy. J Neurol 259(10):20672075. https://doi.org/10.1007/s00415-012-6458-x

19. Vernino S, Low PA, Fealey RD, Stewart JD, Farrugia G, Lennon VA (2000) Autoantibodies to ganglionic acetylcholine receptors in autoimmune autonomic neuropathies. N Engl J Med 343(12):847855. https://doi.org/10.1056/nejm200009213431204

20. Vernino S, Lindstrom J, Hopkins S, Wang Z, Low PA (2008) Characterization of ganglionic acetylcholine receptor autoantibodies. J Neuroimmunol 197(1):63-69. https://doi.org/10.1016/j.jneur oim.2008.03.017

21. Vernino S, Adamski J, Kryzer TJ, Fealey RD, Lennon VA (1998) Neuronal nicotinic ACh receptor antibody in subacute autonomic neuropathy and cancer-related syndromes. Neurology 50(6):1806-1813

22. Miglis MG, Racela R, Kaufmann H (2011) Seropositive myasthenia and autoimmune autonomic ganglionopathy: cross reactivity or subclinical disease? Auton Neurosci 164(1-2):87-88. https:// doi.org/10.1016/j.autneu.2011.06.005

23. Wang Z, Low PA, Jordan J, Freeman R, Gibbons CH, Schroeder C, Sandroni P, Vernino S (2007) Autoimmune autonomic ganglionopathy: IgG effects on ganglionic acetylcholine receptor current. Neurology 68(22):1917-1921. https://doi.org/10.1212/01. wnl.0000263185.30294.61

24. Xu W, Gelber S, Orr-Urtreger A, Armstrong D, Lewis RA, Ou CN, Patrick J, Role L, De Biasi M, Beaudet AL (1999) Megacystis, mydriasis, and ion channel defect in mice lacking the alpha3 neuronal nicotinic acetylcholine receptor. Proc Natl Acad Sci USA 96(10):5746-5751 
25. Lennon VA, Ermilov LG, Szurszewski JH, Vernino S (2003) Immunization with neuronal nicotinic acetylcholine receptor induces neurological autoimmune disease. J Clin Investig 111(6):907-913. https://doi.org/10.1172/jci17429

26. Vernino S, Low PA, Lennon VA (2003) Experimental autoimmune autonomic neuropathy. J Neurophysiol 90(3):2053-2059. https://doi.org/10.1152/jn.00408.2003

27. Mukherjee S, Vernino S (2007) Dysfunction of the pupillary light reflex in experimental autoimmune autonomic ganglionopathy. Auton Neurosci 137(1-2):19-26. https://doi.org/10.1016/j. autneu.2007.05.005

28. Vernino S, Ermilov LG, Sha L, Szurszewski JH, Low PA, Lennon VA (2004) Passive transfer of autoimmune autonomic neuropathy to mice. J Neurosci 24(32):7037-7042. https://doi. org/10.1523/jneurosci.1485-04.2004

29. Baker SK, Chow BM, Vernino SA (2014) Transient neonatal autoimmune autonomic ganglionopathy. Neurol Neuroimmunol Neuroinflamm 1(3):35. https://doi.org/10.1212/nxi.0000000000 000035

30. Li Y, Jammoul A, Mente K, Li J, Shields RW, Vernino S, RaeGrant A (2015) Clinical experience of seropositive ganglionic acetylcholine receptor antibody in a tertiary neurology referral center. Muscle Nerve 52(3):386-391. https://doi.org/10.1002/ mus. 24559

31. Gibbons CH, Freeman R (2009) Antibody titers predict clinical features of autoimmune autonomic ganglionopathy. Auton Neurosci 146(1-2):8-12. https://doi.org/10.1016/j.autne u.2008.11.013

32. Gibbons CH, Vernino SA, Freeman R (2008) Combined immunomodulatory therapy in autoimmune autonomic ganglionopathy. Arch Neurol 65(2):213-217. https://doi.org/10.1001/archn eurol.2007.60

33. Schroeder C, Vernino S, Birkenfeld AL, Tank J, Heusser K, Lipp A, Benter T, Lindschau C, Kettritz R, Luft FC, Jordan J (2005) Plasma exchange for primary autoimmune autonomic failure. N Engl J Med 353(15):1585-1590. https://doi. org/10.1056/NEJMoa051719

34. Muppidi S, Vernino S (2013) Autoimmune autonomic failure. Handb Clin Neurol 117:321-327. https://doi.org/10.1016/b9780-444-53491-0.00025-0

35. Iodice V, Kimpinski K, Vernino S, Sandroni P, Fealey RD, Low PA (2009) Efficacy of immunotherapy in seropositive and seronegative putative autoimmune autonomic ganglionopathy. Neurology 72(23):2002-2008. https://doi.org/10.1212/WNL.0b013 e3181a92b52

36. Iodice V, Kimpinski K, Vernino S, Sandroni P, Low PA (2009) Immunotherapy for autoimmune autonomic ganglionopathy. Auton Neurosci 146(1-2):22-25. https://doi.org/10.1016/j.autne u.2008.11.001

37. Iodice V, Sandroni P (2014) Autonomic neuropathies. Continuum (Minneapolis, Minn) 20:1373-1397. https://doi. org/10.1212/01.con.0000455875.76179.b1

38. Gupta A, Harris S, Vernino S, Naina HV (2015) Rituximabbased therapy and long-term control of autoimmune autonomic ganglionopathy. Clin Auton Res 25(4):255-258. https://doi. org/10.1007/s10286-015-0299-5

39. Imrich R, Vernino S, Eldadah BA, Holmes C, Goldstein DS (2009) Autoimmune autonomic ganglionopathy: treatment by plasma exchanges and rituximab. Clin Auton Res 19(4):259262. https://doi.org/10.1007/s10286-009-0012-7

40. Hollenbeck R, Black BK, Peltier AC, Biaggioni I, Robertson D, Winton EF, Raj SR (2011) Long-term treatment with rituximab of autoimmune autonomic ganglionopathy in a patient with lymphoma. Arch Neurol 68(3):372-375. https://doi.org/10.1001/ archneurol.2010.289
41. Benizri S, Agmon-Levin N, Kitrey ND, Carter D, Goshen E, Sharabi Y (2017) Clinical problem solving: a tobacco merchant who can't spit. Isr Med Assoc J 19(12):786-791

42. Bouxin M, Schvartz B, Mestrallet S, Debrumetz A, Hentzien M, Tabary T, Cohen R, Nicolas G, Bani-Sadr F (2019) Rituximab treatment in seronegative autoimmune autonomic neuropathy and autoimmune autonomic ganglionopathy: case-report and literature review. J Neuroimmunol 326:28-32. https://doi.org/10.1016/j. jneuroim.2018.11.009

43. Dumitrascu OM, McKeon A, Zuniga L, Grill MF, Goodman BP (2017) Opsoclonus-myoclonus syndrome during rituximab treatment for autoimmune autonomic ganglionopathy. Neurol Neuroimmunol Neuroinflamm 4(5):e376. https://doi.org/10.1212/ nxi.0000000000000376

44. Sandroni P, Vernino S, Klein CM, Lennon VA, Benrud-Larson L, Sletten D, Low PA (2004) Idiopathic autonomic neuropathy: comparison of cases seropositive and seronegative for ganglionic acetylcholine receptor antibody. Arch Neurol 61(1):44-48. https ://doi.org/10.1001/archneur.61.1.44

45. Tijero B, Del Pino R, Perez-Concha T, Acera MA, Gabilondo I, Berganzo K, Graus F, Martinez-Alday JD, Barcena J, GomezEsteban JC (2018) Seronegative and seropositive autoimmune autonomic ganglionopathy (AAG): same clinical picture, same response to immunotherapy. J Neuroimmunol 319:68-70. https ://doi.org/10.1016/j.jneuroim.2018.03.018

46. Golden EP, Bryarly MA, Vernino S (2018) Seronegative autoimmune autonomic neuropathy: a distinct clinical entity. Clin Auton Res 28(1):115-123. https://doi.org/10.1007/s10286-017-0493-8

47. Muppidi S (2018) Autoimmune autonomic neuropathies: time to look beyond autoimmune autonomic ganglionopathy. Clin Auton Res 28(1):7-8. https://doi.org/10.1007/s10286-017-0496-5

48. Vernino S, Sandroni P, Singer W, Low PA (2008) Invited article: autonomic ganglia: target and novel therapeutic tool. Neurology 70(20):1926-1932. https://doi.org/10.1212/01.wnl.0000312280 $.44805 .5 \mathrm{~d}$

49. Mukaino A, Minami H, Isomoto H, Hamamoto H, Ihara E, Maeda Y, Higuchi O, Okanishi T, Kokudo Y, Deguchi K, Sasaki F, Ueki T, Murata KY, Yoshida T, Kinjo M, Ogawa Y, Ido A, Matsuo H, Nakao K, Nakane S (2018) Anti-ganglionic AChR antibodies in Japanese patients with motility disorders. J Gastroenterol 53(12):1227-1240. https://doi.org/10.1007/s00535-018-1477-8

50. Vernino S, Hopkins S, Okamoto L, Black B, Dorminy C, Paranjape S, Raj S (2015) Prevalence of ganglionic AChR antibodies in postural tachycardia syndrome (POTS) (P1.276). Neurology 84 (14 Suppl)

51. Vernino S, Bryarly M, Hopkins S, Okamoto LE, Black BK, Paranjape SY, Raj SR (2016) The prevalence of ganglionic AchR antibodies in postural tachycardia syndrome (POTS). Clin Auton Res 26:328

52. Thieben MJ, Sandroni P, Sletten DM, Benrud-Larson LM, Fealey RD, Vernino S, Lennon VA, Shen WK, Low PA (2007) Postural orthostatic tachycardia syndrome: the Mayo Clinic experience. Mayo Clin Proc 82(3):308-313. https://doi.org/10.4065/82.3.308

53. Watari M, Nakane S, Mukaino A, Nakajima M, Mori Y, Maeda Y, Masuda T, Takamatsu K, Kouzaki Y, Higuchi O, Matsuo H, Ando Y (2018) Autoimmune postural orthostatic tachycardia syndrome. Ann Clin Trans Neurol 5(4):486-492. https://doi.org/10.1002/ acn 3.524

54. Li J, Zhang Q, Liao Y, Zhang C, Hao H, Du J (2015) The value of acetylcholine receptor antibody in children with postural tachycardia syndrome. Pediatr Cardiol 36(1):165-170. https://doi. org/10.1007/s00246-014-0981-8

55. Koike H, Watanabe H, Sobue G (2013) The spectrum of immunemediated autonomic neuropathies: insights from the clinicopathological features. J Neurol Neurosurg Psychiatry 84(1):98-106. https://doi.org/10.1136/jnnp-2012-302833 
56. Munetsugu T, Fujimoto T, Oshima Y, Sano K, Murota H, Satoh T, Iwase S, Asahina M, Nakazato Y, Yokozeki H (2017) Revised guideline for the diagnosis and treatment of acquired idiopathic generalized anhidrosis in Japan. J Dermatol 44(4):394-400. https://doi.org/10.1111/1346-8138.13649

57. Colan RV, Snead OC 3rd, Oh SJ, Kashlan MB (1980) Acute autonomic and sensory neuropathy. Ann Neurol 8(4):441-444. https://doi.org/10.1002/ana.410080419

58. Koike H, Atsuta N, Adachi H, Iijima M, Katsuno M, Yasuda T, Fukada Y, Yasui K, Nakashima K, Horiuchi M, Shiomi K, Fukui K, Takashima S, Morita Y, Kuniyoshi K, Hasegawa Y, Toribe Y, Kajiura M, Takeshita S, Mukai E, Sobue G (2010) Clinicopathological features of acute autonomic and sensory neuropathy. Brain 133(10):2881-2896. https://doi.org/10.1093/ brain/awq214

59. Vernino S (2009) Antibody testing as a diagnostic tool in autonomic disorders. Clin Auton Res 19(1):13-19. https://doi. org/10.1007/s10286-008-0488-6

60. De Giorgio R, Guerrini S, Barbara G, Stanghellini V, De Ponti F, Corinaldesi R, Moses PL, Sharkey KA, Mawe GM (2004) Inflammatory neuropathies of the enteric nervous system. Gastroenterology 126(7): 1872-1883

61. Pasha SF, Lunsford TN, Lennon VA (2006) Autoimmune gastrointestinal dysmotility treated successfully with pyridostigmine. Gastroenterology 131(5):1592-1596. https://doi.org/10.1053/j. gastro.2006.06.018

62. Lucchinetti CF, Kimmel DW, Lennon VA (1998) Paraneoplastic and oncologic profiles of patients seropositive for type 1 antineuronal nuclear autoantibodies. Neurology 50(3):652-657

63. Yu Z, Kryzer TJ, Griesmann GE, Kim K, Benarroch EE, Lennon VA (2001) CRMP-5 neuronal autoantibody: marker of lung cancer and thymoma-related autoimmunity. Ann Neurol 49(2):146-154

64. Muppidi S, Vernino S (2014) Paraneoplastic neuropathies. Continuum (Minneapolis, Minn) 20:1359-1372. https://doi. org/10.1212/01.con.0000455876.53309.ec

65. Titulaer MJ, Wirtz PW, Kuks JB, Schelhaas HJ, van der Kooi AJ, Faber CG, van der Pol WL, de Visser M, Sillevis Smitt PA, Verschuuren JJ (2008) The Lambert-Eaton myasthenic syndrome 1988-2008: a clinical picture in 97 patients. J Neuroimmunol 201-202:153-158. https://doi.org/10.1016/j.jneur oim.2008.05.025

66. Wirtz PW, Smallegange TM, Wintzen AR, Verschuuren JJ (2002) Differences in clinical features between the Lambert-Eaton myasthenic syndrome with and without cancer: an analysis of 227 published cases. Clin Neurol Neurosurg 104(4):359-363

67. Lennon VA, Kryzer TJ, Griesmann GE, O'Suilleabhain PE, Windebank AJ, Woppmann A, Miljanich GP, Lambert EH (1995) Calcium-channel antibodies in the Lambert-Eaton syndrome and other paraneoplastic syndromes. N Engl J Med 332(22):14671474. https://doi.org/10.1056/nejm199506013322203

68. Kesner VG, Oh SJ, Dimachkie MM, Barohn RJ (2018) LambertEaton myasthenic syndrome. Neurol Clin 36(2):379-394. https:// doi.org/10.1016/j.ncl.2018.01.008

69. Sawlani K, Katirji B (2017) Peripheral nerve hyperexcitability syndromes. Continuum (Minneapolis, Minn) 23:1437-1450. https ://doi.org/10.1212/con.0000000000000520

70. Irani SR, Pettingill P, Kleopa KA, Schiza N, Waters P, Mazia C, Zuliani L, Watanabe O, Lang B, Buckley C, Vincent A (2012) Morvan syndrome: clinical and serological observations in 29 cases. Ann Neurol 72(2):241-255. https://doi.org/10.1002/ ana. 23577

71. Gadoth A, Pittock SJ, Dubey D, McKeon A, Britton JW, Schmeling JE, Smith A, Kotsenas AL, Watson RE, Lachance DH, Flanagan EP, Lennon VA, Klein CJ (2017) Expanded phenotypes and outcomes among 256 LGI1/CASPR2-IgG-positive patients. Ann Neurol 82(1):79-92. https://doi.org/10.1002/ana.24979
72. Josephs KA, Silber MH, Fealey RD, Nippoldt TB, Auger RG, Vernino S (2004) Neurophysiologic studies in Morvan syndrome. J Clin Neurophysiol 21(6):440-445

73. Singh NK, Jaiswal AK, Misra S, Srivastava PK (1987) Assessment of autonomic dysfunction in Guillain-Barré syndrome and its prognostic implications. Acta Neurol Scand 75(2):101-105

74. Zaeem Z, Siddiqi ZA, Zochodne DW (2018) Autonomic involvement in Guillain-Barré syndrome: an update. Clin Auton Res. https://doi.org/10.1007/s10286-018-0542-y

75. Anandan C, Khuder SA, Koffman BM (2017) Prevalence of autonomic dysfunction in hospitalized patients with Guillain-Barré syndrome. Muscle Nerve 56(2):331-333. https://doi.org/10.1002/ mus. 25551

76. van den Berg B, Walgaard C, Drenthen J, Fokke C, Jacobs BC, van Doorn PA (2014) Guillain-Barré syndrome: pathogenesis, diagnosis, treatment and prognosis. Nat Rev Neurol 10(8):469-482. https://doi.org/10.1038/nrneurol.2014.121

77. Zochodne DW (1994) Autonomic involvement in Guillain-Barré syndrome: a review. Muscle Nerve 17(10):1145-1155. https://doi. org/10.1002/mus.880171004

78. Baysal-Kirac L, Tuzun E, Erdag E, Ulusoy C, Vanli-Yavuz EN, Ekizoglu E, Peach S, Sezgin M, Bebek N, Gurses C, Gokyigit A, Vincent A, Baykan B (2016) Neuronal autoantibodies in epilepsy patients with peri-ictal autonomic findings. J Neurol 263(3):455466. https://doi.org/10.1007/s00415-015-8002-2

79. Dalmau J, Gleichman AJ, Hughes EG, Rossi JE, Peng X, Lai M, Dessain SK, Rosenfeld MR, Balice-Gordon R, Lynch DR (2008) Anti-NMDA-receptor encephalitis: case series and analysis of the effects of antibodies. Lancet Neurol 7(12):1091-1098. https://doi. org/10.1016/s1474-4422(08)70224-2

80. Byun JI, Lee ST, Moon J, Jung KH, Shin JW, Sunwoo JS, Lim JA, Shin YW, Kim TJ, Lee KJ, Park KI, Jung KY, Lee SK, Chu K (2015) Cardiac sympathetic dysfunction in anti-NMDA receptor encephalitis. Auton Neurosci 193:142-146. https://doi. org/10.1016/j.autneu.2015.08.002

81. Tobin WO, Lennon VA, Komorowski L, Probst C, Clardy SL, Aksamit AJ, Appendino JP, Lucchinetti CF, Matsumoto JY, Pittock SJ, Sandroni P, Tippmann-Peikert M, Wirrell EC, McKeon A (2014) DPPX potassium channel antibody: frequency, clinical accompaniments, and outcomes in 20 patients. Neurology 83(20):1797-1803. https://doi.org/10.1212/wnl.0000000000 000991

82. Piepgras J, Holtje M, Michel K, Li Q, Otto C, Drenckhahn C, Probst C, Schemann M, Jarius S, Stocker W, Balint B, Meinck HM, Buchert R, Dalmau J, Ahnert-Hilger G, Ruprecht K (2015) Anti-DPPX encephalitis: pathogenic effects of antibodies on gut and brain neurons. Neurology 85(10):890-897. https://doi. org/10.1212/wnl.0000000000001907

83. Racosta JM, Kimpinski K, Morrow SA, Kremenchutzky M (2015) Autonomic dysfunction in multiple sclerosis. Auton Neurosci 193:1-6. https://doi.org/10.1016/j.autneu.2015.06.001

84. Crnosija L, Krbot Skoric M, Andabaka M, Junakovic A, Martinovic V, Ivanovic J, Mesaros S, Pekmezovic T, Drulovic J, Habek M (2019) Autonomic dysfunction in people with neuromyelitis optica spectrum disorders. Mult Scler J. https://doi. org/10.1177/1352458519837703

85. Chai J, Logigian EL (2010) Neurological manifestations of primary Sjögren's syndrome. Curr Opin Neurol 23(5):509-513. https ://doi.org/10.1097/WCO.0b013e32833de6ab

86. Newton JL, Frith J, Powell D, Hackett K, Wilton K, Bowman S, Price E, Pease C, Andrews J, Emery P, Hunter J, Gupta M, Vadivelu S, Giles I, Isenberg D, Lanyon P, Jones A, Regan M, Cooper A, Moots R, Sutcliffe N, Bombardieri M, Pitzalis C, McLaren J, Young-Min S, Dasgupta B, Griffiths B, Lendrem D, Mitchell S, Ng WF (2012) Autonomic symptoms are common and are associated with overall symptom burden and disease activity in primary 
Sjogren's syndrome. Ann Rheum Dis 71(12):1973-1979. https:// doi.org/10.1136/annrheumdis-2011-201009

87. Imrich R, Alevizos I, Bebris L, Goldstein DS, Holmes CS, Illei GG, Nikolov NP (2015) Predominant glandular cholinergic dysautonomia in patients with primary Sjögren's syndrome. Arthr Rheumatol (Hoboken, NJ) 67(5):1345-1352. https://doi. org/10.1002/art.39044

88. Koh JH, Kwok SK, Lee J, Park SH (2017) Autonomic dysfunction in primary Sjogren's syndrome: a prospective cohort analysis of 154 Korean patients. Kor J Internal Med 32(1):165-173. https:// doi.org/10.3904/kjim.2015.219

89. Mandl T, Granberg V, Apelqvist J, Wollmer P, Manthorpe R, Jacobsson LT (2008) Autonomic nervous symptoms in primary Sjogren's syndrome. Rheumatology (Oxford, England) 47(6):914 919. https://doi.org/10.1093/rheumatology/ken107

90. Ng WF, Stangroom AJ, Davidson A, Wilton K, Mitchell S, Newton JL (2012) Primary Sjogrens syndrome is associated with impaired autonomic response to orthostasis and sympathetic failure. QJM 105(12):1191-1199. https://doi.org/10.1093/qjmed /hcs 172

91. Goodman BP, Crepeau A, Dhawan PS, Khoury JA, Harris LA (2017) Spectrum of autonomic nervous system impairment in Sjögren syndrome. Neurol 22(4):127-130. https://doi. org/10.1097/nrl.0000000000000134

92. Matusik PS, Matusik PT, Stein PK (2018) Heart rate variability in patients with systemic lupus erythematosus: a systematic review and methodological considerations. Lupus 27(8):1225-1239. https ://doi.org/10.1177/0961203318771502

93. Matusik PS, Matusik PT, Stein PK (2018) Cardiovascular reflex tests in patients with systemic lupus erythematosus: clinical performance and utility. Lupus 27(11):1759-1768. https://doi. org/10.1177/0961203318783052

94. Adlan AM, Paton JF, Lip GY, Kitas GD, Fisher JP (2017) Increased sympathetic nerve activity and reduced cardiac baroreflex sensitivity in rheumatoid arthritis. J Physiol 595(3):967-981. https://doi.org/10.1113/jp272944

95. Adlan AM, Lip GY, Paton JF, Kitas GD, Fisher JP (2014) Autonomic function and rheumatoid arthritis: a systematic review. Semin Arthritis Rheum 44(3):283-304. https://doi.org/10.1016/j. semarthrit.2014.06.003

96. Syngle A, Verma I, Krishan P, Garg N, Syngle V (2015) Diseasemodifying anti-rheumatic drugs improve autonomic neuropathy in arthritis: DIANA study. Clin Rheumatol 34(7):1233-1241. https ://doi.org/10.1007/s10067-014-2716-x

97. Amaral TN, Peres FA, Lapa AT, Marques-Neto JF, Appenzeller S (2013) Neurologic involvement in scleroderma: a systematic review. Semin Arthritis Rheum 43(3):335-347. https://doi. org/10.1016/j.semarthrit.2013.05.002

98. Syngle A, Verma I, Garg N, Krishan P (2013) Autonomic dysfunction in psoriatic arthritis. Clin Rheumatol 32(7):1059-1064. https://doi.org/10.1007/s10067-013-2239-x 